BIBLIOTIKA : Jurnal Kajian Perpustakaan dan Informasi

Volume 3 Nomor 1, 2019

Journal homepage $:$ http://journal2.um.ac.id/index.php/bibliotika

\title{
PERAN PERPUSTAKAAN DAN PUSTAKAWAN DALAM MENGHADAPI GENERASI DIGITAL NATIVE
}

\author{
Silvi Oktavia ${ }^{*}$ \\ Universitas Negeri Malang
}

\begin{tabular}{l}
\hline A R T I C L E \\
I N F O \\
\hline
\end{tabular}

Article bistory:

Received: May 2019

Accepted: 23 May 2019

Published: 31 May 2019

Keyword:

Pustakawan; Perpustakaan;

Peran; Era 4.0; Digital

Native

\begin{abstract}
A B S T R A C T
Lingkungan dan teknologi akan terus-menerus berubah. Satusatunya kepastian tentang masa de-pan adalah bahwa secara signifikan berbeda dengan hari ini. Pustakwan harus cerdas membaca tanda zaman agar profesi mereka tidak menuju ke liang kubur sehingga tidak bisa bangkit sela-manya. Apa yang harus dilakukan oleh Pustakawan masa kini sehingga mereka menjadi idaman bagi pemustaka sekarang, sebagai jembatan harapan pustakawan masa depan dalam menghadapi pemustaka yang hadir pada masa mereka. Perpustakaan adalah salah satu unit di lembaga pendidikan yang memiliki peran untuk mendukung pembelajaran sepanjang hayat dengan menyediakan berbagai macam informasi sesuai dengan kebutuhan pengguna. Seiring dengan perkembangan pesat teknologi informasi dan komunikasi, pengguna saat ini telah berubah secara radikal. Mulai dari perilaku mereka dalam mencari informasi dengan memanfaatkan internet, cara mereka belajar sambil bermain game atau mendengarkan musik serta kesenangan mereka dalam berkolaborasi dan berbagi informasi melalui jaringan. Mereka disebut sebagai generasi digital native. Tulisan ini bertujuan untuk menjelaskan dan mengetahui peran, usaha, kemampuan, dan peluang perpustakaan dan pustakawan dalam menghadapi generasi digital native pada era masyarakat informasi. Jenis data kajian ini adalah kualitatif dengan sumber data literature review. Hasil kajian ini menunjukkan bahwa pustakawan sebaiknya meningkatkan kompetensi diri dan melakukan transformasi perpustakaan untuk persiapan menghadapi keberagaman karakteristik generasi digital native.
\end{abstract}

Perpustakaan yang notabene adalah suatu organisasi atau institusi atau lembaga yang bergerak dalam bidang pengolah informasi memiliki peranan penting di masyarakat era terbaru yakni era 4.0 atau disebut juga dengan istilah fourth generation dimana pada era ini teknologi sudah menjadi basis dalam kehidupan masyarakat di tiap waktu. Informasi di era ini merupakan sesuatu yang mudah diperoleh namun kemampuan menelusur informasi yang beredar di masyarakat perlu

\footnotetext{
* Corresponding author.

E-mail addresses: o.silvi.oktavia@gmail.com (Silvi Oktavia)
}

ISSN : 2579-3802 (Online) - BIBLIOTIKA : Jurnal Kajian Perpustakaan dan Informasi is licensed under Creative Commons Attribution-ShareAlike 4.0 International License (http://creativecommons.org/licenses/BY/4.0/). 
dikelola dengan baik. Untuk itulah perpustakaan harus memiliki kemampuan untuk mengatasi hal ini. Wiji Suwarno mengatakan bahwa perpustakaan seperti halnya sebuah organism yangselalu tumbuh dan berkembang. Ia selalu beradaptasi dengan kemajuan zaman, berupayamemahami perkembangan kebutuhan penggunanya, sehingga suatu ketika dapat menjelma menjadi pilihan utama bagi pemustaka dalam menelusur informasi. Inilah sesungguhnya yang dikatakan perpustakaan mengikuti trend, perpustakaan tidak mau ketinggalan zaman (Wiji Suwarno (2016) dalam Indriyana (2017)).

Perpustakaan yang mutakhir sekalipun dengan berbagai teknologi yang terkini tidak akan menarik hati para pemustakanya (istilah yang digunakan untuk sebutan pengguna perpustakaan menurut UU No. 43 tahun 2007 tentang Perpustakaan) apabila tidak didukung dengan kesiapan pengelola perpustakaan dalam mengelola lembaga informasi ini untuk memberikan pelayanan yang maksimal untuk para pemustakanya. Para pengelola perpustakaan disebut dengan istilah pustakawan. Pustakawan merupakan profesi yang memiliki beberapa tugas pokok dan fungsi yang spesifik. Salah satu tugas pustakawan adalah memberikan layanan kepada para pemustakanya, dan untuk itu maka dibutuhkan keterampilan sosial ketika berhadapan dengan pemustaka. Interaksi sosial antara pemustaka dan pustakawan ini merupakan hal yang sangat penting agar keberadaan perpustakaan menjadi salah satu daya tarik dalam kehidupan pemustaka. Dalam abad informasi ini pembangunan sumber daya manusia (SDM) dalam hal ini pustakawan menjadi sangat penting. Pustakawan mempunyai tugas dan peranan untuk mengelola sumber informasi yang semakin berkembang. Upaya peningkatan kualitas sumber daya manusia pengelola informasi merupakan aset dalam menentukan keberhasilan pembangunan masyarakat Indonesia seutuhnya.

Dengan adanya perkembangan teknologi dimasyarakat ini, membuat terciptanya suatu generasi masyarakat baru yang disebut Generasi Digital atau Digital Native.Digital Native adalah generasi muda yang lahir saat internet telah menjadi bagian hidup mereka (Helsper \& Enyon (2009, h. 1)). Jim Marteney (2010) mengemukakan terkait generasi manusia yang dikutip pada tulisan milik Hasugian (2011) membagi generasi manusia dalam 6 kategori yaitu: (a) the Greatest Generation (world war II, 1901-1924), (b) the Silent Generation (1925-1942); (c) the Baby Boomers (1943-1960); (d) Generasi X (19611981); (e) Millennial (1982-2002); (f) Digital Natives (Generasi Z atau Internet Generation), mulai tahun 1994 sampai akhir tahun sekarang. Pada generasi manusia terbaru ini atau disebut dengan The Native Gadget mengganggap bahwa perangkat komunikasi sebagai bagian integral dari kehidupannya. Sedangkan orang-orang yang tidak lahir pada abad digital tetapi mengadopsi teknologi baru dianggap sebagai digital immigrants, karena ada proses adaptasi pada lingkungan dengan mengadopsi teknologi. Individu yang lahir pada abad digital, tumbuh dan memperoleh pendidikan pada tingkat sekolah dasar dengan perangkat komputer, individu tersebut dianggap sebagai generasi digital natives. Mulai dari pendidikan dasar sudah dihadapkan dengan penggunaan komputer, seperti, kuiz interaktif online, video games, handphone, internet, e-mail dan sebagainya. Sedangkan guru dianggap sebagai generasi digital immigrants yang bisa saja keterampilan literasi komputer didapatkan pada masa kuliah atau memasuki dunia kerja.

Tulisan ini akan menyoroti peran perpustakaan dalam menghadapi tantangan baru dalam terciptanya generasi Digital Native saat ini. Hali ini karena perpustakaan merupakan upaya untuk memelihara dan meningkatkan efisiensi dan efektifitas proses belajar-mengajar. Perpustakaan yang terorganisasi secara baik dan sistematis, secara langsung atau pun tidak langsung dapat memberikan kemudahan bagi proses belajar mengajar di sekolah atau perguruan tinggi tempat perpustakaan tersebut berada maupun pada masyarakat umum sebagai tempat untuk penerapan pembelajaran sepanjang hayat.

\section{PEMBAHASAN}

\section{Generasi Digital Native}

Pemakaian kata digital natives pertama kali digunakan oleh Marc Prensky pada tahun 2001 untuk menggambarkan satu generasi "native speakers" yang terbiasa dengan lingkungan digital 
atau teknologi digital dan internet. Generasi digital natives banyak menghabiskan waktunya untuk menggunakan komputer, videogames, digital music players, kamera video, telpon seluler, serta berbagai macam mainan lain dan peralatan dari era digital. Games komputer, e-mail, internet, telpon seluler dan pesan instan menjadi bagian yang tidak terlepaskan dari kehidupan mereka. Digital native memiliki beberapa ciri khas yang membedakannya dengan generasi sebelumnya, setidaknya dalam hal-hal berikut ini: Pertama, identitas. Digital native cenderung ribut soal identitas. Mereka begitu peduli dengan ke"ada"an diri mereka. Karena itulah mereka ramai-ramai membuat akun di Facebook, Twitter, Youtube, dan lain-lain untuk membuktikan kepada dunia bahwa mereka ada. Sikap ingin dianggap atau bisa disebut juga dengan narsis ini menjadi wajar karena mereka memang menemukan media yang bisa memuaskan hasrat mereka untuk eksis.

Kedua, privasi. Generasi digital native memiliki sifat yang cenderung lebih terbuka, blakblakan, dan open minded. Jika mereka bilang suka, mereka bilang suka, dan jika tidak suka, mereka akan bilang tidak suka. Mereka juga merasa tidak masalah "membuka" apa yang disebut oleh generasi sebelum mereka sebagai privasi. Mereka malah berlomba-lomba membuka kehidupan privasi mereka di status Facebook .

Ketiga, kontrol dan kebebasan. Generasi digital native gila kebebasan. Mereka tidak suka diatur dan dikekang. Mereka ingin memegang kontrol, dan internet menawarkan hal itu. Jika mereka tidak suka suatu website, mereka bisa menutupnya saat itu juga. Mereka juga bebas untuk menolak atau menerima permintaan pertemanan di Facebook. Sebaliknya, jika mereka mendukung sesuatu, mereka akan berbondong-bondong mendukungnya dengan fanatik. Dalam proses bekerjasama dengan generasi digital native cukup sederhana yakni dengan cara duduk bersama mereka, libatkan untuk berpartisipasi. Buat tujuan bersama-sama mereka dan minta saran kritik dari mereka. Biarkan mereka mengambil keputusan.

Keempat, proses belajar. Perbedaan antara generasi digital native dengan digital imigrant terletak pada proses belajar. Generasi digital native jengah ketika disuruh membaca Encyclopedia Brittanica, tapi mereka tahu banyak hal. Hal ini bisa terjadi karena mereka selalu mencari di search engine Google dan search engine lain. Kemampuan belajar mereka jauh lebih cepat karena segala informasi ada di ujung jari mereka.

Dengan mengetahui kecenderungan beberapa karakter Generasi digital native, membuat tidak akan heran lagi mengapa pertumbuhan Facebook, You Tube, dan Twitter begitu cepat, hal ini terjadi karena di situs-situs itulah Generasi digital native menemukan diri mereka. Di sana mereka dapat narsis, eksis, dan menjadi diri mereka sendiri. Mereka juga mempunyai kebebasan dan kontrol. Di sana mereka bisa berbagi notes Facebook, link bermutu di Twitter, ataupun video inspiratif di Youtube. Sementara, situs lainnya yang dianggap tidak sesuai dengan kebutuhan mereka, lama - kelamaan akan ditinggalkan dan hilang ditelan jaman. Fenomena ini bisa terjadi karena seluruh dunia sedang berubah dengan begitu cepat.

Data terbaru dari Google consumer behaviour yang dituliskan Kemp(2019, h.1) menyatakan bahwa Indonesia yang total populasinya 268,2 juta memiliki 50\% pengguna internet. Separuh dari pengguna internet di Indonesia adalah generasi digital native.

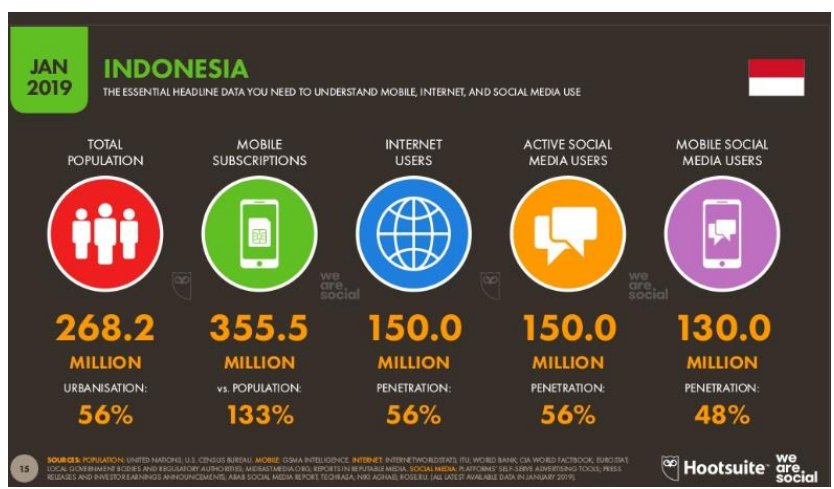

Gambar 1.1 Jumlah Pengguna Internet di Indonesia Tahun 2019 (Januari) Sumber: Kemp (2019, b. 1) 
Dari hasil data statistik tersebut sudah terlihat betapa besarnya generasi digital native yang telah berkembang di masyarakat saat ini. Ku \& Soulier (2009); Gaith (2010) mengartikan generasi digital natives dengan karakteristik sebagai berikut: menikmati aktivitas dalam lingkungan yang serba online, misalnya lebih sering menciptakan hubungan pertemanan secara online; sesegera mungkin mendapatkan informasi, berkolaborasi secara berjejaring, mencari informasi secara acak, karena itu lebih menyukai informasi berbasis hypertext. Cara mendapat informasi, jika memungkinkan informasi diperoleh secara instan.

Dalam melakukan aktivitas, cenderung bekerja dengan multitasking atau secara pararel dalam kurun waktu bersamaan; lebih suka memproses informasi visual secara dinamis, menikmati informasi berbentuk gambar interaktif, khususnya games yang interaktif; Disamping itu pula keinginan agar pendapat mereka dihargai oleh prang lain; Informasi yang diterima langsung diyakini sebagai suatu fakta; Informasi langsung dibagikan kepada orang lain tanpa dicari sumber keasliannya; dan judul berita dianggap sebagai sebuah kesimpulan. Penggunaan teknologi informasi tidak hanya berdampak pada aktivitas sosial, tetapi pengaruh teknologi pada generasi digital natives dapat dilihat juga terhadap gaya belajarnya.

Hal ini sesuai dengan penelitian yang dilakukan Ghaith (2010), gaya belajar generasi digital natives, dengan ciri-ciri: cara belajar dengan cepat, memproses informasi secara cepat, walaupun pada akhirnya tidak bisa berkonsentrasi dengan baik, karena mencari informasi serba cepat dalam waktu singkat. Kecenderungan generasi digital natives yang serba cepat dan instan menjadikan mereka lebih memilih melakukan browsing informasi, tanpa mau berlama-lama membaca informasi dengan lengkap. Aktivitas browsing dan reading informasi memiliki perbedaan terutama pada pengalaman yang diperoleh dari aktivitas tersebut. Seseorang mendapatkan informasi dari buku, memiliki eksperien berbeda ketika pengguna membaca buku dengan melakukan browsing informasi di internet. Kegiatan browsing bersifat dinamis, artinya jika mengakses suatu situs informasi yang ditampilkan di internet hari ini akan berbeda konten dalam hari berikutnya. Pengalaman membaca buku bersifat statik, artinya kebaruan konten buku tidak secepat kebaruan informasi dalam sebuah situs. Disamping itu, pembaca tidak akan kehilangan makna buku tersebut, meskipun sudah dicetak berkali-kali atau berganti edisi.

Berbagai pendapat di atas dapat disimpulkan generasi digital natives merupakan generasi yang dilingkupi dengan lingkungan berbasis teknologi, bekerja dengan cara multitasking, berjejaring dengan banyak orang, menyukai suatu permainan yang interaktif, akses informasi secara acak, ingin segera mendapatkan informasi secara instan, cepat, tanpa harus membaca informas secara detail, pilihan rujukan informasi dominan pada sumber-sumber yang tersedia online, dibanding sumber informasi yang disediakan perpustakaan. Perilaku orang dalam mengadopsi teknologi dipengaruhi dari adanya teknologi yang muncul di setiap generasi yang berbeda.

\section{Perpustakaan Dulu Versus Perpustakaan Sekarang}

Perpustakaan merupakan suatu lembaga yang bergerak dalam bidang informasi, mulai menghimpun, mengolah sampai pada penyebaran informasi tersebut. Beberapa masa terakhir ini, dunia teks atau tercetak mendapat tantangan dari temuan temuan teknologi baru. Dengan adanya perkembangan atau kemajuan ilmu pengetahuan dan teknologi (IPTEK), perpustakaan pun dituntut untuk mampu beradaptasi dengan hal tersebut. Perpustakaan pada era baru ini benar benar dipilih sebagai salah satu pelaku perubahan (agent of change). Hal ini dapat dikatakan seperti itu karena perpustakaan merupakan tempat berbagi informasi tersimpan didalamnya dan disini pula sesungguhnya embrio intelektual diciptakan. Dahulu perpustakaan dianggap sebagai tempat buku saja, kini berkembang menjadi pusat sumber daya informasi. Artinya, perpustakaan tidak lagi sebagai penyimpan buku semata, tetapi menjadi tempat yang mampu menciptakan nilai tambah bagi pemustaka, yang bermanfaat bagi orang lain. Banyak perpustakaan saat ini yang mulai atau telah mengemas ulang maupun mengembangkan koleksinya dalam bentuk digital. 
Namun sejenak kita tengok fungsi perpustakaan yang memiliki dua paradigma perpustakaan yakni paradigma lama dan paradigma baru.

\section{Paradigma Lama}

Sulistyo - Basuki (1991) sebagai bapak perpustakaan di Indonesia memberikan gambaran fungsi perpustakaan dalam kehidupan masyarakat sebagai berikut: (a) Fungsi Simpan Karya, yaitu fungsi perpustakaan untuk menyimpan buah karya masyarakat. Bentuk karya yang disimpan adalah yang berkaitan dengan buku, majalah, surat kabar, atau informasi terekam lainnya. Perpustakaan berfungsi sebagai "arsip umum" bagi produk masyarakat berupa buku dalam arti luas. (b) Fungsi Informasi, yaitu fungsi perpustakaan yang memberikan informasi yang dikelola perpustakaan kepada pemustakanya. Pada fungsi ini, anggota masyarakat yang memerlukan informasi dapat meminta atau menanyakannya ke perpustakaan. Informasi yang dikelola berupa informasi mengenai tugas sehari - hari, pelajaran, atau informasi lainnya. (c) Fungsi Pendidikan, yaitu fungsi perpustakaan yang menunjang sistem pembelajaran yang dicanangkan oleh pemerintah. Perpustakaan merupakan sarana pendidikan nonformal dan informal. Artinya, perpustakaan merupakan tempat belajar diluar bangku sekolah maupun juga tempat belajar didalam lingkungan pendidikan sekolah. Dalam hal ini, yang berkaitan dengan pendidikan nonformal adalah perpustakaan umum, sedangkan yang berkaitan dengan pendidikan informal adalah perpustakaan sekolah atau perpustakaan perguruan tinggi. (d) Fungsi Rekreasi, yaitu fungsi perpustakaan sebagai tempat yang menjadi rekreasi bagi pemustakanya dengan memberikan fasilitas yang baik dan bacaan yang sifatnya menghibur. (e) Fungsi Kultural, yaitu fungsi perpustakaan sebagai media dalam rangka mengembangkan berbagai kebudayaan yang dituangkan dalam suatu karya.

\section{Paradigma Baru}

Perkembangan zaman menuntut perubahan pola pikir masyarakat agar mampu beradaptasi dengan baik pada situasi dan kondisi yang ada. Demikian pula dengan paradigma perpustakaan yang dituntut mampu mengikuti perkembangan ilmu pengetahuan dan teknologi (IPTEK). Diantaranya adalah : (a) Simpan Pinjam Karya. Sebagaimana tertuang dalam UU No.43 Tahun 2007 bahwa koleksi perpustakaan diseleksi, dilayankan, disimpan dan dikembangkan sesuai dengan kepentingan pemustaka. (b) Pusat Sumber Daya Informasi (SDI), yaitu fungsi perpustakaan yang menggali dan mengelola informasi, yang dapat menjadi bahan bagi pemustaka untuk menghasilkan karya baru yang dapat diakses oleh pemustaka lainnya sebagai informasi yang baru. Sebagaimana yang tertuang dalam UU No.43 Tahun 2007 bahwa koleksi perpustakaan diseleksi, dilayankan, disimpan, dan dikembangkan sesuai dengan kepentingan pemustaka dengan memerhatikan perkembangan teknologi informasi dan komunikasi. Dalam hal ini terdapat dua pesan bagi pustakawan agar mengembangkan sistem cari - kelola informasi dan segaligus cepat tanggap terhadap informasi baru. (c) Pusat Sumber Belajar dan Penelitian Masyarakat, yaitu fungsi perpustakaan sebagai tempat belajar dan penelitian bagi masyarakat sehingga menjadi masyarakat yang cerdas dan berpengrtahuan luas. Pasal 2 UU No.43 Tahun 2007 menyebutkan bahwa perpustakaan diselenggarakan berdasarkan asas pembelajaran sepanjang hayat. Dalam ayat lain pun dijelaskan bahwa perpustakaan bertujuan memberikan layanan kepada pemustaka serta memperluas wawasan dan pengetahuan untuk mencerdaskan kehidupan bangsa. (d) Rekreasi dan Re-Kreasi, yaitu fungsi perpustakaan sebagai tempat yang nyaman dan menyajikan informasi informasi yang sifatnya menyenangkan, serta sebagai tempat yang menghasilkan kreasi (karya) baru yang berpijak dari karya - karya orang lain yang telah dipublikasikan. (e) Mengembangkan Kebudayaan, yaitu fungsi perpustakaan sebagai tempat mengembangkan kebudayaan melalui informasi yang disajikan, serta penanaman nilai - nilai kepada masyarakat melalui berbagai kegiatan - kegiatannya. Berkaitan dengan nilai, dikembangkan pula sikap pelayanan dengan semakin ditekankannya pustakawan untuk memahami karakter pemustaka. Tidak disangkal lagi bahwa trend center dari pelayanan ini merujuk pada pelayanan bank, yaitu tempat pelayanan 
terhadap nasabah yang berorientasi kepuasan pelanggan. Kepuasan pelanggan sangat diperhatikan sehingga dikenal slogan pelayanan 4 S, yaitu senyum, sapa, sopan, dan santun.

\section{Peran Perpustakaan di Era Digital Native}

Peran adalah kedudukan, posisi, dan tempat yang dimainkan. Perpustakaan harus menjadi agen perubahan yang cukup menantang, perlu adanya pengembangan perpustakaan yang mendukung keberadaan generasi digital native konsep Smart Library atau perpustakaan pintar yang berbasis teknologi merupakan jawaban bagi kebutuhan generasi digital natives di perpustakaan. Konsep ini didasarkan pada pemanfaatan teknologi secara menyeluruh terutama yang berbasis online dan mobile, layanan $24 \times 7$, layanan anywhere anytime, dan layanan yang berbasis 'ruang komunikasi' yang lebih lebar antara pustakawan dengan pemustakanya.

Perpustakaan sedang menghadapi tantangan kemajuan teknologi informasi dan komunikasi (TIK). Gadget hadir sebagai alat multifungsi yang cerdas dan memberi banyak kemudahan, ini menandai adanya konverjensi, sebuah kecenderungan kemajuan TIK. Kecenderungan lain yang harus diakui adalah disintermediasi yaitu berkurangnya kebutuhan hadirnya perantara sebuah komunikasi atau transaksi. Sebagai contoh, melalui pemanfaatan gadget yang digenggamnya pemustaka dapat melihat katalog, berinteraksi secara praktis, dan melakukan transaksi berbagai layanan.

Di era generasi digital native ini sudah banyak perpustakaan yang menerapkan dan menggunakan teknologi digital dalam kegiatan perpustakaan, baik itu pelayanan kepada pemustaka maupun kegiatan teknis sehari-hari, terutama di negara negara maju.Perpustakaan dilengkapi dengan sistem aplikasi perpustakaan yang lengkap, canggih seperti sistem one search yang diciptakan oleh Perpustakaan Nasional RI, penggunaan sistem layanan mandiri dengan berbasis RFID (radio frequency identification), sistem teknologi komunikasi, student consultation, dan lain sebagainya. Perpustakaan benar benar difungsikan tidak sebatas ruang dan gedung, tetapi lebih dari itu, dimanapun dan kapanpun dapat mengakses perpustakaan dengan hanya satu sentuhan .

Perpustakaan di era generasi digital native hendaknya mulai berfikir untuk menyediakan fasilitas akses konten multimedia lewat jaringan internet, mengembangkan koleksi tematik yang sesuai dengan lokalitas pengguna, serta mempunyai gaya yang informal / kasual seperti di jejaring social,memberikan layanan telekomunikasi jarak jauh dengan pemustaka. Layanan tersebut berbentuk layanan email, twitter, mobile dan jejaring social lainnya yang menggunakan jasa telekomunikasi. Pemustaka bebas mengajukan request kepada pustakawan dalam dua puluh empat jam dan pustakawan siap untuk melayani.

\section{Peran Pustakawan dalam Menghadapi Generasi Digital Native}

Pustakawan merupakan salah satu komponen penting perpustakaan yang diperlukan untuk memberikan pelayanan (jasa) kepada pengguna perpustakaan sampai mampu memberikan tingkat kepuasan terhadap masyarakat yang dilayani. Pustakawan seharusnya merupakan tenaga fungsional yang statusnya tidak berbeda dengan tenaga profesional lainnya. Oleh karena itu, masa depan seorang pustakawan harus mampu menempa dirinya menjadi seorang profesional yang mampu memberikan jasa dan memberi pelayanan yang memuaskan kepada pelanggannya, baik menggunakan maupun mentransfer menggunakan peralatan manual atau digital, teknologi tradisional ataupun teknologi elektronika yang canggih.

Karena adanya tuntutan zaman maka perubahan model layanan perpustakaan telah pindah dari pustakawan yang berperan untuk memberikan koleksi menunju pustakawan yang mempersiapkan dan menciptakan akses ke semua data yang tersedia pada pemustaka, sehingga dapat memenuhi kebutuhan informasi para pengguna. Pustakawan mempelajari ilmu informasi dan bagaimana bekerja dengan klien untuk membantu mereka menemukan solusi untuk kebutuhan informasi mereka. Pustakawan juga harus belajar dengan cepat bahwa ada suatu seni untuk bekerja dengan orang-orang, untuk menemukan jawaban atas pertanyaan-pertanyaan sulit 
dengan menggunakan sumber daya yang tersedia dan dalam mengetahui mana sumber daya informasi yang digunakan untuk menemukan informasi yang sedang dicari dalam waktu singkat.

Selain itu, pustakawan juga harus menjadi : (a) Mampu secara strategis melakukan pencarian informasi dalam basis data maupun internet. (b) memberi konsultasi maupun referensi pencarian informasi bisa dengan melalui chatting (instan messaging), e-mail (electronic mail), maupun daring yang melalui telfon. (c) Menggunakan mesin pencari dan web directories. (c) Mengetahui analisis terkait berita hoax dan mencegah penyebarannya. (d) Menjadi komunikator yang baik, dan ramah kepada pengguna.

Untuk dapat memenuhi peran pustakwan masa kini kita dapat mempertimbangkan pendapat Coghill, Jeffrey G., and Roger G. Russell (2016) yang menyaranakan agar pustakawan memiliki keterampilan secara umum berikut: (a) Adaptasi-Seberapa baik Anda beradaptasi dengan perubahan? Database mengubah antarmuka sepanjang waktu. Bisa Anda, sebagai pustakawan, beradaptasi dari salah satu cara dalam melakukan sesuatu dan beralih ke cara lain untuk melakukan tugas yang sama?. (b) Fleksibilitas-Tidak lagi pustakawan duduk di meja referensi menunggu pelanggan mereka untuk datang ke mereka. Sebaliknya, kita harus bertemu pelanggan di mana mereka bekerja atau tinggal. Bisa Anda, sebagai pustakawan, perubahan dengan waktu? Anda dapat bekerja dengan beberapa klien konstituen dan perubahan untuk memenuhi kebutuhan mereka? Meskipun tidak ada satu orang dapat menguasai kekayaan informasi yang dibuat setiap hari, pustakawan bisa menjadi "generalis" yang memiliki pemahaman dasar tentang berbagai subjek untuk klien mereka.(c) Kemampuan untuk multitasking- Begitu banyak perangkat teknologi yang harus dikuasai. hubungan interpersonal yang harus dibangun dan dipelihara. Pustakawan tidak lagi terbatas pada empat dinding perpustakaan, tetapi keluar ke "alam liar" untuk bertemu klien atau pelanggan di mana mereka bekerja dan di mana mereka membutuhkan bantuan. Dan dapat bekerja pada beberapa proyek dengan beberapa konstituen sekaligus. (d) Kreativitas-Dapatkah Anda menemukan cara baru untuk melayani pemustaka perpustakaan Anda? Apakah ada cara baru dan program di perpustakaan Anda yang dapat menarik lebih banyak pengguna? Simpanlah rasa malu anda dan menjadi pustakawan yang lebih akrab melalui iklan atau promosi yang bisa menyenangkan pustaka dan hasil yang mengejutkan.

Salah satu perubahan transisi yang bersifat akomodatif adalah mengajak generasi digital native sebagai partner dalam pencarian kebutuhan informasi bukan dengan mengabaikan kebutuhan mereka yang begitu kompleks. Dan yang paling terpenting lagi yang perlu diingat adalah kenali karakteristik pemustaka generasi digital native lebih dalam.

Fourie, Denise K., and Nancy E. Loe (2016) menambahkan 10 penerapan kelompok profesi Pustakawan yang dapat diterapkan pada era masa kini yakni : (a) Pustakawan Referensi dan penelitian (Reference and research librarians) adalah pustakawan yang mengkhususkan diri dalam subjek tertentu dan memiliki pengetahuan luas tentang literatur profesional di berbagai bidang. Mereka juga mengajarkan pengguna cara penggunaan database secara efektif dan alat referensi lainnya. (b) Pustakawan Referensi dan penelitian (Reference and research librarians) adalah pustakawan yang mengkhususkan diri dalam subjek tertentu dan memiliki pengetahuan luas tentang literatur profesional di berbagai bidang. Mereka juga mengajarkan pengguna cara penggunaan database secara efektif dan alat referensi lainnya. (c) Pustakawan layanan teknis (Technical services librarians) adalah pustakawan mengelola akuisisi, pengembangan koleksi, dan katalog.Mereka mengalokasikan dana untuk departemen perpustakaan dan program, pilih vendor, mengawasi perintah dan langganan, dan katalogisasi cetak dan sumber daya digital. Mereka juga menganalisis dan menilai koleksi perpustakaan terhadap standar profesional dan tolok ukur, dan membuang atau menambahkan bahan seperti yang ditunjukkan. (d) Pustakawan Serials (Serials librarians) adalah pustakawan mengelola majalah, jurnal, dan majalah yang diterbitkan secara berkala. Mereka mengawasi langganan, pembaharuan, dan memperbarui catatan bibliografi ketika serial mengubah nama atau menghentikan penerbitan. Seperti serial terus bermigrasi dari cetak ke format digital, pustakawan ini semakin melakukan pekerjaan pustakawan sumber daya elektronik dijelaskan sebelumnya. (e) Pustakawan Katalogisasi (Cataloging librarians) adalah pustakawan 
mengawasi bagaimana cetak dan bahan digital siap untuk pengguna, dari menandai bahan pustaka dengan perangko kepemilikan menciptakan catatan bibliografi yang menyediakan akses intelektual bagi pengguna. Pustakawan ini harus memahami dan menerapkan metadata sesuai dengan standar profesional. (f) Pustakawan Sistem (Systems librarians) adalah pustakawan mengelola teknologi informasi untuk perpustakaan. Mereka memilih dan mempertahankan hardware dan software, atau sistem terpadu perpustakaan (ILS), digunakan di perpustakaan. Mereka mengelola server, sistem operasi, database, aplikasi, dan upgrade; menciptakan dan memelihara sistem backup dan rencana pemulihan bencana; dan melindungi sistem perpustakaan dari malware dan serangan. Mereka mengawasi programmer, digital pustakawan media, dan desainer Web yang merancang cara informasi digital dikirim ke pengguna. (g) Pustakawan koleksi khusus (Special collections librarians) adalah pustakawan mengelola bahan yang unik dan sering sejarah, termasuk manuskrip, buku, foto, dan dokumen, mengumpulkan oleh subjek, jangka waktu, dan / atau wilayah. Pustakawan ini memperoleh bahan, biasanya dengan sumbangan; mengatur dan menggambarkan mereka untuk kepentingan umum; dan menyeimbangkan kebutuhan untuk melindungi bahan rapuh dengan permintaan untuk digunakan oleh para peneliti. (h) Pustakawan layanan digital (Digital services librarians) adalah pustakawan posisi relatif baru, berfokus pada menciptakan, menerapkan, dan memelihara konten digital yang dibuat terutama di perpustakaan akademik, arsip, dan koleksi khusus. Mereka mengembangkan dan mempertahankan repositori institusional; menerapkan strategi preservasi digital; mengembangkan koleksi perpustakaan digital baru; menjangkau mengajar fakultas untuk mengintegrasikan koleksi ini ke dalam kurikulum; dan membantu mengembangkan teknologi dalam mendukung inisiatif digital di kampus. (i) Pustakawan sekolah (School librarians) adalah pustakawan bekerja secara langsung dengan K-12 siswa untuk memenuhi kebutuhan pendidikan mereka. Pustakawan sekolah (juga dikenal sebagai guru-pustakawan) juga bekerja sama dengan instruktur kelas untuk mengidentifikasi dan menyediakan bahan- bahan digital dan cetak yang melengkapi kurikulum resmi. (j) Direktur perpustakaan (Library directors) adalah administrator yang mengelola sebuah sumber daya manusia perpustakaan, koleksi, dan jasa. Mereka memimpin organisasi mereka untuk dapat merspon tren dan perkembangan dalam profesi, serta teknologi saat ini dan masa depan. Direktur perpustakaan melaporkan kepada atasan mereka, ke pejabat pemerintah, atau menginformasikan lewat papan pengumuman perpustakaan. Mereka juga bertanggung jawab untuk mengidentifikasi dan mengamankan aliran pendanaan baru, misalnya berupa hadiah, hibah, dan sumber-sumber eksternal lainnya.

\section{PENUTUP}

Generasi digital natives merupakan generasi yang dilingkupi dengan lingkungan berbasis teknologi, bekerja dengan cara multitasking, berjejaring dengan banyak orang, menyukai suatu permainan yang interaktif, akses informasi secara acak, ingin segera mendapatkan informasi secara instan, cepat, tanpa harus membaca informas secara detail, pilihan rujukan informasi dominan pada sumber-sumber yang tersedia online, dibanding sumber informasi yang disediakan perpustakaan. Perilaku orang dalam mengadopsi teknologi dipengaruhi dari adanya teknologi yang muncul di setiap generasi yang berbeda.

Perpustakaan di era digital native yang sudah melek teknologi informasi mempunyai tugas yang berat dikarenakan daya, usaha, dana untuk menyediakan layanan dan fasilitas yang dibutuhkan pemustaka sangat terbatas. Salah satu perubahan transisi yang bersifat akomodatif adalah mengajak generasi digital native sebagai partner dalam pencarian kebutuhan informasi bukan dengan mengabaikan kebutuhan mereka yang begitu kompleks. Dan yang paling terpenting lagi yang perlu diingat adalah kenali karakteristik pemustaka generasi digital native lebih dalam. Disamping itu terdapat 10 contoh penerapan bidang pustakawan yang dapat diterapkan di perpustakaan, yakni Pustakawan Referensi dan penelitian (Reference and research librarians), Pustakawan pelayanan publik (Public service librarians), Pustakawan layanan teknis (Technical services librarians), Pustakawan Serials (Serials librarians), Pustakawan Katalogisasi (Cataloging 
librarians), Pustakawan Sistem (Systems librarians), Pustakawan koleksi khusus (Special collections librarians), Pustakawan layanan digital (Digital services librarians), Pustakawan sekolah (School librarians), dan Direktur perpustakaan (Library directors). Hal utama dalam pemberian layanan yang sesuai dengan kebutuhan para pemustaka, utamanya generasi digital, adalah kemauan dan motivasi tinggi dari para pustakawan untuk mengubah keadaan yang ada.

\section{DAFTAR RUJUKAN}

Fourie, Denise K., and Nancy E. Loe. Libraries in the Information Age: An Introduction and Career Exploration: An Introduction and Career Exploration. Santa Barbara: ABC-CLIO, 2016).h.9

Ghaith, G. (2010). An exploratory study of the achievement of the twenty-first century skills in higher education. Education \& Training, 52 (6/7), 489-498. Diakses melalui https://www.researchgate.net/publication/235255028 An exploratory study of the achi evement of the twenty-first century skills in higher education. Diakses tanggal 13 Mei 2019 Pukul 22.05

Hasugian J. 2011. Perpustakaan Digital dan Digital Natives Disampaikan pada seminar dan workshop nasional Pemberdayaan Repository... di U.H. Nommensen Medan, 1-12- 2011. Diakses

pada http://repository.usu.ac.id/bitstream/handle/123456789/64595/Digital Natives.pdf?sequ ence $=1$ \&isAllowed $=\mathrm{y}$. Diakses tanggal 13 Mei 2019 pukul 21.41

Helsper, E., \& Enyon, R. 2009. Digital natives: Where is the evidence? British Educational Research Journal,

$1-18$. http://eprints.lse.ac.uk/27739/1/Digital_natives_\%28LSERO\%29.pdf

https://datareportal.com/reports/digital-2019-indonesia. Data Statistik Pengguna Internet di Indonesia tahun 2019.

Indriyani, Kholifah. 2017. Digital Native sebagai Tantangan dan Peluang pada Pengembangan Layanan Perpustakaan. (Jurnal Online). https://www.academia.edu/33882862/DIGITAL NATIVES SEBAGAI TANTANGA N DAN PELUANG PADA PENGEMBANGAN LAYANAN PERPUSTAKAAN. Diakses tanggal 12 Mei 2019 pukul 29.05

Jamridafrizal. 2017. Siapkah Pustakawan Menghadapi Era Digital ? Al-Maktabah Vol. 16, Desember 2017. Diakses pada http://journal.uinjkt.ac.id/index.php/almaktabah/article/download/8087/4397.

$\mathrm{Ku}$, D.T., \& Soulier, J.S. (2009). Effects of learning goals on learning performance of field-dependent and field-independent late adolescent in a hypertext environment. Adolescence, 651-664.

Suwarno, Wiji. 2016. Ilmu Perpustakaan \& Kode Etik Pustakawan. Ar-Ruzz Media, Yogyakarta. 